\title{
Patterns of heterochromatin distribution in plant chromosomes
}

\author{
Marcelo Guerra \\ Departamento de Botânica, CCB, Universidade Federal de Pernambuco, Cidade Universitária, \\ 50670-420 Recife,PE, Brasil.E-mail:mguerra@npd.ufpe.br
}

\begin{abstract}
The C-band distribution patterns of 105 angiosperm species were compared to identify general patterns or preferential sites for heterochromatin. The base-specific fluorochrome reaction of heterochromatin for 58 of these species and the role played by the average chromosome size in band distribution were also considered. The results showed that heterochromatin was preferentially located in similar chromosome regions, regardless of the distance from the centromere. This trend results in generalized bands, with heterochromatin distribution being identical in most chromosomes of a karyotype. Such bands very often displayed the same fluorochrome reaction, suggesting possible repeat transfer between non-homologous sites. Chromosome size may also play a role in heterochromatin location, since proximal bands were much more common in small-sized chromosomes.
\end{abstract}

\section{INTRODUCTION}

Heterochromatin $(\mathrm{HC})$ is one of the chromosomal components that has attracted most attention from cytogeneticists, because of its still unknown function, its apparent lack of genes and the fact that it stains differently to the rest of the chromosome. Especially after the development of $\mathrm{HC}$ differentiation techniques in the metaphase chromosomes of a great diversity of organisms, a large number of papers were written which reported its presence, variability, molecular composition, direct and indirect effects on the karyotype, putative function, etc. (see Mizianty, 1984a,b, 1985; John, 1988; Hennig, 1999). One of the most basic, but by no means the least important aspects of $\mathrm{HC}$ research, is the study of its distribution in blocks or bands throughout the karyotype. Analysis of band distribution patterns can make it possible to verify whether the bands are preferentially located in certain chromosomal regions, suggesting that the $\mathrm{HC}$ has a functional purpose.

\section{HETEROCHROMATIN VARIABILITY}

The analysis of HC distribution patterns in the chromosome complement of angiosperms in general is hindered by the particularly high variability of HC added to the variability of other karyotype parameters. The comparison of $\mathrm{HC}$ band patterns of different species should take into consideration the following aspects: 1) the $\mathrm{HC}$ is not homogeneous, varying qualitatively and quantitatively between species; 2) within a single species, polymorphism for the number and size of bands is frequent; 3 ) the amount of $\mathrm{HC}$ varies regardless the amount of euchromatin or the nuclear DNA content; 4) both HC and euchromatin can suffer large changes in a relatively short time; 5) different staining techniques may reveal different $\mathrm{HC}$ fractions; 6 ) very different species may present simultaneous differences in chromosome number, size and morphology, as well as in the amount, composition and distribution of HC (Greilhuber, 1982; Vosa, 1985; John, 1988; Sumner, 1990).

The functional and evolutionary meaning of $\mathrm{HC}$ may not be the same for all species, and a single distribution pattern for all angiosperms may not exist, only tendencies or preferential patterns for different genomes and karyotype architectures.

In spite of these difficulties in establishing general models, some authors draw attention to distribution patterns that seem to occur very frequently. Heitz (1933) was the first to observe that, in each species, the $\mathrm{HC}$ seemed to be distributed non-randomly in proximal, interstitial and telomeric regions. In Vicia faba, for instance, he observed that $\mathrm{HC}$ was preferentially located in interstitial regions, while in Allium cepa it distribution was preferentially terminal. After performing chromosome analysis of several species of plants and animals, Heitz (1957) considered that such an equilocal distribution is a universal rule.

Lima de Faria (1976a,b, 1983) considered that heterochromatin blocks observed by "cold starvation" or by C-banding, as well as chromomeres, knobs, secondary constrictions and other chromosomal markers and DNA sequences, would occupy preferential sites within the chromosome field (the chromosome region between centromere and telomere where specific DNA sequences and chromosome phenomena occur in a specific order). Greilhuber (1979), however, re-examined the available data on the distribution of "cold starved" $\mathrm{HC}$ and found no preferential regions.

Later, Loidl and collaborators (Loidl, 1983; Greilhuber and Loidl, 1983; Schweizer and Loidl, 1987) drew attention to the fact that in many species HC blocks tend to be distributed in the arms of different chromosomes at an equal distance starting from the centromere (see also Bennett, 1982). In such cases, the chromosomes would tend to exhibit equidistant bands (e.g., on the telomeres of similar-sized arms and in the corresponding interstitial regions 
of the longest arms), while, according to Heitz, the distribution of bands would be preferentially equilocal (e.g., on the telomeres of short and long arms). These tendencies would result in different karyotype patterns, with equilocalization producing a generalized banding pattern in all chromosomes of a complement (regardless of size and centromeric index variation), while equidistance would generate different banding patterns in asymmetrical karyotypes and identical patterns in symmetrical karyotypes.

\section{HETEROCHROMATIN CHARACTERIZATION}

One of the difficulties in understanding $\mathrm{HC}$ distribution is the fact that bands of a single karyotype may be composed of different types of $\mathrm{HC}$, i.e., unrelated families of repetitive DNA with independent distribution patterns (Flavell, 1982). Therefore, it is important to separately evaluate the distribution of each HC type by cyto-molecular techniques, as has been done for rye (Appels et al., 1978), Scilla (Deumling and Greilhuber, 1982), barley (Brandes et al., 1995), Aegilops (Badaeva et al., 1996) and a few other organisms. Working with conventional cytological techniques, only the $\mathrm{HC}$ associated with the nucleolar organizer region (NOR-HC) can be specifically identified, due to secondary constrictions or by silver nitrate impregnation. More reliable recognition of the NOR-HC has recently been achieved by in situ hybridization, mainly with $\mathrm{pTa} 71$ probe, which is able to localize rDNA $18 \mathrm{~S}-5.8 \mathrm{~S}-26 \mathrm{~S}$ sites in every kind of plant (see, e.g., Galasso et al., 1996a; Hizume et al., 1992) and at least in some animals (Pendás et al., 1993). An alternative way of distinguishing some $\mathrm{HC}$ types is to stain the chromosomes with fluorochromes that have a preferential affinity for AT- or GC-rich DNA. This staining can differentiate the $\mathrm{HC}$ in only a few groups, allowing the easy observation of their distribution in the chromosomes.

HC may be revealed by different cytological techniques, with identical or very similar results (Vosa, 1976b; Lozano et al., 1990; Berg and Greilhuber, 1993). Conventional staining techniques may sometimes show heteropycnotic regions that form the so-called prophase condensation patterns (Fukui and Mukai, 1988; Ikeda, 1988; Benko-Iseppon and Morawetz, 1993). Such regions have often been confused with $\mathrm{HC}$ patterns which may be very different from each other (see Morawetz, 1981a; Guerra, 1988a). The HC revealed by C-banding seems to correspond to the most general conception of $\mathrm{HC}$, coinciding with the sites of late replicating DNA and tandem organized satellite DNA (Baumann, 1971; Appels et al., 1978; Deumling and Greilhuber, 1982; Cortés and Escalza, 1986; Schubert and Rieger, 1991). However, the use of different $\mathrm{C}$-banding techniques may result in very different banding patterns. In Citrus, for example, HC blocks were found mostly at terminal regions (Guerra, 1985, 1993a; Miranda et al., 1997; Pedrosa et al., 2000), although Ito et al. (1993), using a different technique, found exclusively proximal HC blocks. In corn, Aguiar-Perecin and Vosa (1985) reported
C-bands in terminal and subterminal chromosomal regions, coinciding in number and position with the knobs. However, Molina (1981) found only proximal bands in all the chromosomes, while Chow and Larter (1981) found proximal and terminal bands. On the other hand, Carvalho and Saraiva (1993), using another technique (KHG banding), found numerous interstitial bands. In all these cases the bands were clear and unequivocal, and the differences in these results were certainly due to the procedures used, which revealed different chromatin fractions.

Besides the C-banding technique, staining with basespecific fluorochromes has been recognized as a reliable method of distinguishing some types of $\mathrm{HC}$ in plants (Vosa, 1970, 1976b; Schweizer, 1976). The fluorochromes quinacrine (Q), Hoechst $33258(\mathrm{H})$ and 4'-6-diamidino-2phenylindole (DAPI) preferentially stain AT-rich $\mathrm{HC}\left(\mathrm{Q}^{+}\right.$, $\mathrm{H}+$ and DAPI+ bands, respectively) while mitramycin (MM) and chromomycin A3 (CMA) preferentially stain GCrich $(\mathrm{MM}+$ or $\mathrm{CMA}+$ ) regions (Schweizer, 1976; Sumner, 1990). These same fluorochromes may also negatively stain AT-poor or GC-poor HC blocks, respectively, whereas double staining with two fluorochromes of different base specificity (e.g., CMA/DAPI, CMA/H or MM/DAPI) may highlight staining differences (Schweizer, 1976, 1981; Kenton, 1991). In addition, non-fluorescent DNA-ligands, like dystamycin A, may also be used to intensify the CMA or DAPI staining (Schweizer, 1983; Fuchs et al., 1998). However, not all AT-rich or GC-rich $\mathrm{HC}$ reacts equally to these fluorochromes (see e.g., Schwarzacher and Schweizer, 1982; Kenton, 1991; Bennett et al., 1995) and some C-banded positive regions react neutrally with fluorochromes, i.e., they fluoresce with the same brightness as euchromatin (Morawetz, 1986a,b; Röser, 1994; Galasso et al., 1996b; Cuellar et al., 1996). Other C-bands, fluoresce with the same intensity when stained with fluorochromes with different base-specificities, such as CMA and DAPI (Loidl, 1983; Guerra, 1989; Okada, 1991; Berg and Greilhuber, 1993). All these $\mathrm{HC}$ types were considered here as neutral bands.

In this paper the C-band distribution patterns of 105 species, belonging to 58 dicotyledons and 32 monocotyledons genera, were compared in order to identify general patterns of $\mathrm{HC}$ distribution or any preferential sites in which it may occur. Only the results obtained with the C-banding techniques most used in plants (Marks, 1975; Schwarzacher et al., 1980; Gill et al., 1991) will be considered. These techniques are based on chromosome hydrolysis with $45 \%$ acetic acid, or dilute hydrochloric acid, followed by denaturation in barium hydroxide, treatment with $2 \mathrm{x}$ SSC and Giemsa staining. Information about the reactivity to basespecific fluorochromes is included for 58 of these species. The main questions focused on are: 1) Is there a preferential distribution of C-bands in the proximal, interstitial or telomeric regions? 2) Are band distribution patterns influenced by the average chromosome size of the karyotypes? 3) Is there any relationship between GC-rich or ATrich $\mathrm{HC}$ bands and their chromosomal location? 4) Is the 
occurrence of generalized equilocal bands influenced by their base composition, their chromosomal position, or the average chromosome size?

\section{MATERIAL ANALYZED: CRITERIA FOR DATA SELECTION}

To evaluate the variability of $\mathrm{HC}$ distribution patterns among angiosperms, data were compiled for 105 species belonging to 90 genera (Table I). Each species name was preceded by the first three letters of its family name to help recognize the taxa, along with diploid number, average chromosome size, band position in the chromosomes, occurrence and position of generalized bands and consulted references.

Species were selected for inclusion in this list simply because they were published or unpublished author's original data or because they were cited in papers available to the author. To avoid overrepresenting the banding patterns of more widely studied plant groups, such as Triticum, Hordeum, etc., only a single species of each genus was considered. However, in genera with large karyotype variation, either in the amount or the distribution of $\mathrm{HC}$, like Capsicum and Scilla, two or more representatives were included. In these cases preference was given to the species with extreme $\mathrm{HC}$ patterns and to those about which data was available for both C-band and fluorochrome staining. The references used were always those with good photographic documentation which was compatible with the description in the text, the photographic data generally being more highly valued than the text description. Papers with no photographic data were not considered.

The sample was divided into three groups according

Table I - C-band distribution in plant karyotypes with small, medium and large average chromosome size (ACS). Generalized bands (G) may be located at the telomeric (T), interstitial (I) and proximal (P) regions. Family names are indicated by the three first letters (ANA = Anacardiaceae, ANN = Annonaceae, etc). Numbers after species names identify the fluorochromes used: 1, DAPI; 2, quinacrine; 3, Hoechst 33258; 4, CMA.

Heterochromatin with main base composition identified but without any indication of fluorochrome used was stained with CMA/DAPI. NOR associated bands are identified by number, position (T, I or P), and AT or GC richness; base composition not defined = ?; number in brackets are NOR sites without C-bands. Estimated values are indicated by ca. (circa).

\begin{tabular}{|c|c|c|c|c|c|c|c|c|}
\hline \multirow[t]{2}{*}{ Family-species } & \multirow[t]{2}{*}{$2 \mathrm{n}$} & \multirow[t]{2}{*}{ ACS } & \multicolumn{4}{|c|}{ Heterochromatin distribution } & \multirow[t]{2}{*}{ G } & \multirow[t]{2}{*}{ References } \\
\hline & & & $\mathrm{T}$ & I & $\mathrm{P}$ & NOR & & \\
\hline \multicolumn{9}{|l|}{ Small chromosomes $(<3.0 \mu \mathrm{m})$} \\
\hline ANA-Anacardium occidentale & 40 & 1.1 & $4 \mathrm{GC}$ & - & - & $2 \mathrm{~T}-\mathrm{GC}$ & - & Gitaí and Guerra (1999) \\
\hline ANN-Porcelia goyazensis & 18 & ca.2.8 & 4 & - & 6 & $2 \mathrm{~T}$ & - & Morawetz (1984) \\
\hline ANN - Guatteria schlechtendaliana & 28 & ca.2.0 & - & - & $28 \mathrm{~N}$ & $2 \mathrm{GC}$ & $\mathrm{P}$ & Morawetz and Waha (1985) \\
\hline ARA - Hedera helix & 48 & ca.2.5 & - & $2 \mathrm{GC}$ & $48 \mathrm{~N}$ & 2I-GC & $\mathrm{P}$ & König et al. (1987) \\
\hline ARE - Johannesteijsmannia altifrons & 34 & ca.2.0 & - & - & 34AT & $2 \mathrm{~T}-\mathrm{GC}$ & $\mathrm{P}$ & Röser (1994) \\
\hline ARI - Thottea siliquosa & 26 & ca. 1.8 & 2 & - & 26 & - & $\mathrm{P}$ & Morawetz (1985) \\
\hline AST - Artemisia capillaris & 18 & 2.4 & 6 & - & 18 & - & $\mathrm{P}$ & Mendelak and Schweizer (1986) \\
\hline AST - Emilia sonchifolia & 10 & 2.5 & - & - & $10 \mathrm{~N}$ & $2 \mathrm{~T}-\mathrm{GC}$ & $\mathrm{P}$ & $\begin{array}{l}\text { Guerra and Nogueira (1990) } \\
\text { Guerra, M. (unpublished data) }\end{array}$ \\
\hline AST - Helianthus anпииs & 34 & ca.2.8 & - & - & $34 \mathrm{~N}$ & $6 \mathrm{~T}-\mathrm{GC}$ & $\mathrm{P}$ & Cuellar et al. (1996) \\
\hline BIG - Jacaranda macrantha & 36 & ca.2.3 & 4 & - & 36 & $4 \mathrm{~T}$ & $\mathrm{P}$ & Morawetz (1982) \\
\hline BRA - Arabidopsis thaliana ${ }^{1}$ & 10 & ca. 1.5 & - & - & 10AT & 4AT(?) & $P$ & $\begin{array}{l}\text { Ambros and Schweizer (1976); } \\
\text { Maluszynska and Heslop- } \\
\text { Harrison (1991) }\end{array}$ \\
\hline BRA - Raphanus sativus & 18 & ca.3.0 & - & - & 18 & $2 \mathrm{~T}$ & $\mathrm{P}$ & Hirai et al. (1995) \\
\hline BRA - Sinapsis alba & 24 & ca.2.0 & 4 & - & 24 & - & $\mathrm{P}$ & Geber and Schweizer (1988) \\
\hline CAP - Lonicera caprifolium & 18 & ca.2.0 & 14 & - & 18 & - & $\mathrm{P}$ & Benko-Iseppon and Morawetz (1993) \\
\hline CUC - Cucumis sativus & 14 & ca.1.9 & 24 & - & 8 & 2I & $\mathrm{T}$ & Ramachandran et al. (1985) \\
\hline EUP - Manihot esculenta & 36 & 1.8 & $4 \mathrm{GC}$ & $2 \mathrm{~N}$ & - & 4T-GC & - & Carvalho and Guerra (1999) \\
\hline FAB - Arachis hypogaea & 40 & 2.13 & 6 & 10 & 40 & 2I & $\mathrm{P}$ & $\begin{array}{l}\text { Cai et al. (1987); Fernández and } \\
\text { Krapovickas (1994) }\end{array}$ \\
\hline FAB - Cicer arietinum & 16 & ca. 2.8 & - & $\begin{array}{c}2 \mathrm{GC} \\
+4 \mathrm{AT}\end{array}$ & 16AT & $2 \mathrm{I}-\mathrm{GC}$ & $\mathrm{P}$ & Galasso et al. (1996a) \\
\hline FAB - Medicago sativa & 16 & ca. 2.3 & 12 & $16 \mathrm{~N}$ & $16 \mathrm{~N}$ & 2I-GC & $\mathrm{I}+\mathrm{P}$ & $\begin{array}{l}\text { Masoud et al. (1991); } \\
\text { Calderini et al. }(1996)\end{array}$ \\
\hline FAB - Phaseolus calcaratus & 22 & 1.4 & - & - & 22 & $2 \mathrm{~T}$ & $\mathrm{P}$ & Zheng et al. (1991) \\
\hline FAB - Vigna ambacensis & 20 & ca.2.8 & $8 \mathrm{GC}$ & - & $20 \mathrm{~N}$ & - & $\mathrm{P}$ & Galasso et al. (1996b) \\
\hline FAB - Vigna sesquipedalis & 22 & 2.0 & 6 & 3 & 22 & $2 \mathrm{~T}$ & $\mathrm{P}$ & Zheng et al. (1991) \\
\hline MAG - Liriodendron tulipifera & 38 & ca. 1.3 & 28 & - & 7 & - & $\mathrm{T}$ & Morawetz (1981a) \\
\hline MON - Peumus boldus & 78 & 2.9 & - & - & 78 & $12 \mathrm{~T}$ & $\mathrm{P}$ & Morawetz (1981b) \\
\hline ORC - Orchis coriophora ${ }^{3}$ & 36 & ca. 2.5 & 20AT & - & - & $(12 \mathrm{I})$ & - & D'Emerico et al.(1996) \\
\hline RUT - Boenninghausenia albiflora & 20 & ca.1.8 & - & - & 20 & - & $\mathrm{P}$ & Guerra (1985b) \\
\hline RUT - Citrus hystrix & 18 & ca.2.0 & ca.13 & - & ca. 10 & $2 \mathrm{~T}$ & - & Guerra (1985b) \\
\hline RUT - Coleonema pulchrum & 34 & ca. 1.5 & - & - & 12 & $2 \mathrm{~T}$ & - & Guerra (1985b) \\
\hline
\end{tabular}


Table I - Continued

\begin{tabular}{|c|c|c|c|c|c|c|c|c|}
\hline \multirow[t]{2}{*}{ Family-species } & \multirow[t]{2}{*}{$2 \mathrm{n}$} & \multirow[t]{2}{*}{ ACS } & \multicolumn{4}{|c|}{ Heterochromatin distribution } & \multirow[t]{2}{*}{ G } & \multirow[t]{2}{*}{ References } \\
\hline & & & $\mathrm{T}$ & I & $\mathrm{P}$ & NOR & & \\
\hline RUT - Glycosmis pentaphylla & 54 & ca. 2.0 & - & - & - & 6T-GC & - & $\begin{array}{l}\text { Guerra et al. (in press); } \\
\text { Guerra, M. and Santos, K.G.B. } \\
\text { (unpublished data) }\end{array}$ \\
\hline RUT - Murraya paniculata & 18 & ca. 2.3 & $18 \mathrm{GC}$ & - & $4 \mathrm{~N}$ & 2P-GC & $\mathrm{T}$ & $\begin{array}{l}\text { Guerra (1985b); Guerra et al. } \\
\text { (in press) }\end{array}$ \\
\hline SAP - Cardiospermum grandiflorum & 20 & 2.4 & $12 \mathrm{AT}$ & - & - & $4 \mathrm{~T}-\mathrm{GC}$ & - & Hemmer and Morawetz (1990) \\
\hline SAP - Serjania subdentata & 24 & 2.2 & $12 \mathrm{AT}$ & - & - & $6 \mathrm{~T}-\mathrm{GC}$ & - & Hemmer and Morawetz (1990) \\
\hline SOL - Solanum tuberosum & 24 & ca.2.7 & 10 & 12 & 18 & 2I & - & Pijnacker and Ferwerda (1984) \\
\hline VEL - Vellozia pattens & 16 & ca. 0.8 & - & - & $16 \mathrm{~N}$ & $4 \mathrm{~T}-\mathrm{GC}$ & $P$ & Melo et al. (1997) \\
\hline \multicolumn{9}{|l|}{ Medium chromosomes $(>3.0<5.0 \mu \mathrm{m})$} \\
\hline ANN - Annona muricata & 14 & ca.3.0 & $4 \mathrm{~N}$ & - & $6 \mathrm{AT}+8 \mathrm{~N}$ & 2P-GC & $\mathrm{P}$ & Morawetz (1986a) \\
\hline ANN - Rollinia pulchrinervis & 42 & 4.0 & - & - & $\begin{array}{l}18 \mathrm{~N}+20 \mathrm{AT} \\
\quad+4 \mathrm{GC}\end{array}$ & $4 \mathrm{~T}-\mathrm{GC}$ & $\mathrm{P}$ & Morawetz (1986b) \\
\hline ARE - Coccothrinax litoralis & 36 & ca.3.9 & - & $2 \mathrm{AT}$ & $36 \mathrm{~N}$ & $2 \mathrm{~T}-\mathrm{GC}$ & $\mathrm{P}$ & Röser(1994) \\
\hline ARE - Schippia concolor & 36 & ca.3.9 & - & - & $36 \mathrm{~N}$ & $2 \mathrm{P}-\mathrm{GC}$ & $\mathrm{P}$ & Röser (1994) \\
\hline AST - Crepis capillaris & 6 & 4.7 & 4 & 8 & 4 & $2 \mathrm{~T}$ & $\mathrm{~T}$ & Siljak-Yakovlev and Cartier (1979) \\
\hline AST - Lactuca sativa & 18 & ca.3.2 & - & 20 & 18 & $4 \mathrm{~T}$ & $\mathrm{P}$ & Koopman et al. (1993) \\
\hline CAP - Viburnum opulus & 18 & ca. 4.0 & $14 \mathrm{GC}$ & ca.10GC & - & 2T-GC & $\mathrm{T}$ & Benko-Iseppon and Morawetz (1993) \\
\hline COM - Callisia sp. & 24 & ca.5.5 & - & - & 24 & - & $\mathrm{P}$ & Jones and Kenton (1984) \\
\hline COS-Costus pulverulentus & 18 & ca.3.5 & - & - & 18AT & $2 \mathrm{~T}-\mathrm{GC}$ & $\mathrm{P}$ & Guerra (1988a) \\
\hline FAB - Lathyrus aphaca ${ }^{2}$ & 14 & 3.9 & $12 \mathrm{AT}$ & $18 \mathrm{AT}$ & - & $(2 \mathrm{I})$ & - & $\begin{array}{l}\text { Rees and Hazarika (1969); } \\
\text { Ünal et al. (1995) }\end{array}$ \\
\hline FAB - Lathyrus tingitanus ${ }^{2}$ & 14 & 4.5 & $2 \mathrm{AT}$ & $\begin{array}{c}2 \mathrm{GC} \\
+24 \mathrm{AT}\end{array}$ & $14 \mathrm{GC}$ & (2I) & $\mathrm{I}+\mathrm{P}$ & $\begin{array}{l}\text { Rees and Hazarika (1969); } \\
\text { Ünal et al. (1995) }\end{array}$ \\
\hline FAB - Sesbania tetraptera & 12 & 4.6 & - & - & $12 \mathrm{~N}$ & $4 \mathrm{~T}-\mathrm{GC}$ & $P$ & $\begin{array}{l}\text { Forni Martins et al. (1994); } \\
\text { Forni Martins and Guerra (1999) }\end{array}$ \\
\hline FAB - Vicia johannis & 14 & ca.4.1 & 12 & - & - & $2 \mathrm{I}$ & $\mathrm{T}$ & Ramsay (1984) \\
\hline FAB - Vicia lutea & 14 & ca.4.7 & 14 & 18 & - & $2 \mathrm{~T}$ & $\mathrm{~T}+\mathrm{I}$ & Ramsay (1984) \\
\hline GOO - Scaevola taccada & 16 & ca.4.0 & - & - & $16 \mathrm{~N}$ & $2 \mathrm{~T}-\mathrm{GC}$ & $\mathrm{P}$ & Morawetz (1986a) \\
\hline HYA - Fortunatia arida ${ }^{2}$ & 34 & 3.6 & 29AT & 3АT & - & - & $\mathrm{T}$ & Fernandez and Daviña (1991) \\
\hline HYA - Muscari comosum & 18 & ca.3.0 & - & 8AT & 18AT & $2 \mathrm{GC}(?)$ & $\mathrm{P}$ & Lozano et al. (1990) \\
\hline IRI - Eleutherine bulbosa & 12 & 3.3 & $1 \mathrm{~N}$ & $4 \mathrm{AT}$ & $12 \mathrm{AT}$ & $2 \mathrm{P}-\mathrm{GC}$ & $\mathrm{P}$ & Guerra (1988b) \\
\hline ORC - Cephalanthera longifolia & 32 & 3.4 & - & $2 \mathrm{AT}$ & $32 \mathrm{AT}$ & 2I-GC & $\mathrm{P}$ & Schwarzacher and Schweizer (1982) \\
\hline ORC - Psygmorchis pusilla & 12 & 3.8 & - & - & $12 \mathrm{~N}$ & - & $\mathrm{P}$ & Felix and Guerra (in press) \\
\hline POA - Milium effusum & 28 & 3.3 & 44 & - & 10 & $4 \mathrm{I}$ & $\mathrm{T}$ & Bennett and Thomas (1991) \\
\hline POA - Zea mays & 20 & ca.4.5 & 8 & 20 & - & $2 \mathrm{I}$ & I & $\begin{array}{l}\text { Aguiar-Perecin (1985); } \\
\text { Aguiar-Perecin and Vosa (1985) }\end{array}$ \\
\hline POA - Zingeria biebersteiniana ${ }^{1,2,3}$ & 4 & ca.4.9 & $8 \mathrm{~N}$ & $10 \mathrm{~N}$ & $4 \mathrm{AT}$ & $2 \mathrm{GC}$ & $\begin{array}{c}\mathrm{T}+ \\
\mathrm{I}+\mathrm{P}\end{array}$ & Bennett et al. (1995) \\
\hline RUB - Genipa americana & 22 & ca.4.0 & ca. $24 \mathrm{GC}$ & ca.12GC & ca.10GC & 2T-GC & $\mathrm{T}$ & $\begin{array}{l}\text { Guerra (1993b); Pierozzi and } \\
\text { Mendaçolli (1997) }\end{array}$ \\
\hline RUT - Dictamnus albus & 36 & ca.3.5 & 72 & - & - & - & $\mathrm{T}$ & Guerra (1985b) \\
\hline SOL - Capsicum anпuum & 24 & 4.1 & ca. $24 \mathrm{GC}$ & $2 \mathrm{GC}$ & - & $4 \mathrm{~T}-\mathrm{GC}$ & $\mathrm{T}$ & $\begin{array}{l}\text { Moscone et al. }(1993,1996) ; \\
\text { Moscone, E. (personal } \\
\text { communication) }\end{array}$ \\
\hline SOL - Capsicum pubescens & 24 & 3.9 & $\begin{array}{c}2 \mathrm{AT} \\
+32 \mathrm{GC}\end{array}$ & $\begin{array}{l}2 \mathrm{GC} \\
+2 \mathrm{~N}\end{array}$ & $24 \mathrm{~N}$ & $4 \mathrm{~T}-\mathrm{GC}$ & $\mathrm{T}+\mathrm{P}$ & $\begin{array}{l}\text { Moscone et al. }(1993,1996) \\
\text { Moscone, E. (personal } \\
\text { communication) }\end{array}$ \\
\hline \multicolumn{9}{|l|}{ Large chromosomes (>5.0 $\mu \mathrm{m})$} \\
\hline ADO - Adoxa moschatellina & 36 & 5.8 & 45 & 1 & - & $7 \mathrm{~T}$ & $\mathrm{~T}$ & Greilhuber (1979) \\
\hline ALL - Allium fistulosum ${ }^{2}$ & 16 & ca.11.5 & $30 \mathrm{GC}$ & $4 \mathrm{~N}$ & ca. $14 \mathrm{~N}$ & $2 \mathrm{~T}-\mathrm{GC}$ & $\mathrm{T}+\mathrm{P}$ & Kamizyô and Tanaka (1978) \\
\hline ALL - Allium subvillosum & 28 & ca.5.4 & $26 \mathrm{GC}$ & $19 \mathrm{GC}$ & $28 \mathrm{GC}$ & $6 \mathrm{~T}-\mathrm{GC}$ & $\mathrm{T}+\mathrm{P}$ & Jamilena et al. (1990) \\
\hline ALL - Nothoscordum cf pulchellum & 10 & 14.3 & - & - & - & 2T-GC & - & $\begin{array}{l}\text { Felix, L.P. and Guerra, M. } \\
\text { (unpublished data) }\end{array}$ \\
\hline ALL - Nothoscordum fragrans & 19 & ca. 16.0 & $2 \mathrm{AT}$ & $6 \mathrm{GC}$ & - & $5 \mathrm{~T}-\mathrm{GC}$ & - & $\begin{array}{l}\text { Sato and Yoshioka (1984); } \\
\text { Crosa (1996) }\end{array}$ \\
\hline ALL - Tulbaghia pulchella ${ }^{2}$ & 12 & 10.5 & $11 \mathrm{GC}$ & - & - & (2P) & $\mathrm{T}$ & Dyer (1963); Vosa (1970) \\
\hline ALS - Alstroemeria magnifica & 16 & 7.4 & 2 & 11 & - & $6 \mathrm{I}$ & - & Buitendijk et al. (1998) \\
\hline ALS - Alstroemeria ligtu & 16 & 14.9 & 14 & ca.46 & 16 & $6 \mathrm{P}$ & $\mathrm{T}+\mathrm{I}+\mathrm{P}$ & Buitendijk et al. (1998) \\
\hline AST - Anacyclus "coronatus" & 18 & 6.0 & ca.20 & 4 & 18 & $6 \mathrm{~T}$ & $\mathrm{~T}+\mathrm{P}$ & Schweizer and Ehrendorfer (1976) \\
\hline AST - Anacyclus depressus & 18 & 6.1 & - & - & 18 & $4 \mathrm{~T}$ & $\mathrm{P}$ & Schweizer and Ehrendorfer (1976) \\
\hline
\end{tabular}


Table I - Continued

\begin{tabular}{|c|c|c|c|c|c|c|c|c|}
\hline \multirow[t]{2}{*}{ Family-species } & \multirow[t]{2}{*}{$2 n$} & \multirow[t]{2}{*}{ ACS } & \multicolumn{4}{|c|}{ Heterochromatin distribution } & \multirow[t]{2}{*}{ G } & \multirow[t]{2}{*}{ References } \\
\hline & & & $\mathrm{T}$ & I & $\mathrm{P}$ & NOR & & \\
\hline AST - Artemisia judaica & 16 & 6.0 & 16 & - & 13 & $6 \mathrm{~T}$ & $\mathrm{~T}+\mathrm{P}$ & Mendelak and Schweizer (1986) \\
\hline AST - Crepis praemorsa & 8 & 9.2 & 13 & ca. 15 & - & - & $\mathrm{T}$ & Siljak-Yakovlev and Cartier (1979) \\
\hline AST - Crepis vesicaria & 8 & 6.2 & - & - & 8 & $2 \mathrm{~T}$ & $\mathrm{P}$ & Guerra (1982) \\
\hline AST - Hypochoeris brasiliensis & 8 & 7.8 & - & - & 6 & $2 \mathrm{I}+2 \mathrm{C}$ & $\mathrm{P}$ & Ruas et al. (1995) \\
\hline AST - Santolina sp. & 36 & 6.1 & ca.66 & - & ca.32 & $4 \mathrm{~T}$ & $\mathrm{~T}+\mathrm{P}$ & Guerra, M. (unpublished data) \\
\hline BOR - Buglossoides purpurocaerulea ${ }^{2}$ & 16 & ca. 5.9 & $20 \mathrm{GC}$ & $20 \mathrm{GC}$ & - & $(4 \mathrm{I})$ & $\mathrm{T}+\mathrm{I}$ & D'Amato et al. (1981) \\
\hline COM - Gibasis karwinskyana ${ }^{1,4}$ & 10 & 11.2 & 18AT & $10 \mathrm{AT}$ & - & $2 \mathrm{~T}-\mathrm{GC}$ & $\mathrm{T}+\mathrm{I}$ & Kenton (1978); Kenton (1991) \\
\hline FAB - Vicia faba & 12 & ca.9.5 & - & ca.46AT & 2AT & 2I-GC & I & Greilhuber (1975); Fuchs et al. (1998) \\
\hline FAB - Vicia melanops & 10 & ca.11.6 & $8 \mathrm{AT}$ & ca.20AT & - & $3 \mathrm{I}-\mathrm{GC}$ & $\mathrm{T}$ & D’Amato et al. (1980) \\
\hline HYA - Hyacinthoides italica & 16 & 11.2 & 12 & ca.24 & 16 & $2 \mathrm{P}$ & $\mathrm{I}+\mathrm{P}$ & König and Ebert (1997) \\
\hline HYA - Ornithogalum tenuifolium ${ }^{2}$ & 6 & 5.1 & - & - & - & 2P-GC & - & Vosa (1997) \\
\hline HYA - Prospero autumnale & 12 & ca.7.7 & - & 8AT & $12 \mathrm{AT}$ & $2 \mathrm{GC}$ & $\mathrm{P}$ & Ebert et al. (1996) \\
\hline HYA - Puschkinia scilloides & 10 & 5.5 & 6 & - & - & $2 \mathrm{~T}+4 \mathrm{I}$ & - & Greilhuber and Speta (1976) \\
\hline HYA - Scilla mischtschenkoana & 12 & 10.0 & $1 \mathrm{AT}$ & ca.14 AT & - & 4T-GC & I & $\begin{array}{l}\text { Greilluber and Speta (1978); } \\
\text { Deumling and Greilhuber (1982) }\end{array}$ \\
\hline HYA - S. persica & 8 & 13.8 & - & - & - & $2 \mathrm{~T}$ & - & Greilhuber and Speta (1978) \\
\hline HYA - S. siberica & 12 & 15.0 & $10 \mathrm{GC}$ & $5 \mathrm{GC}$ & $12 \mathrm{AT}$ & 2P-GC & $\mathrm{T}+\mathrm{P}$ & $\begin{array}{l}\text { Greilhuber and Speta (1978); } \\
\text { Deumling and Greilhuber (1982) }\end{array}$ \\
\hline LIL - Bulbine alata & 28 & 5.1 & 36 & 4 & 28 & $2 \mathrm{~T}$ & $\mathrm{~T}+\mathrm{P}$ & Watson (1988) \\
\hline LIL - Lilium canadense & 24 & ca.16.0 & - & 50 & 24 & $4 \mathrm{~T}$ & $\mathrm{I}+\mathrm{P}$ & Smyth et al. (1989) \\
\hline LIL - Tulipa gesneriana ${ }^{2,3,4}$ & 24 & ca.11.0 & 36 & ca.36 & - & - & $\mathrm{T}+\mathrm{I}$ & Blakey and Vosa (1982) \\
\hline ORC - Cypripedium segawai & 20 & ca. 13.8 & $24 \mathrm{AT}$ & $61 \mathrm{AT}$ & 20AT & $(2 \mathrm{P})$ & $\mathrm{T}+\mathrm{I}+\mathrm{P}$ & $\begin{array}{l}\text { Kondo et al. (1994); } \\
\text { Hoshi et al. (1995) }\end{array}$ \\
\hline PAE - Paeonia tenuifolia & 10 & 19.1 & - & - & $10 \mathrm{~N}$ & 6T-GC & $\mathrm{P}$ & Schwarzacher-Robinson (1986) \\
\hline POA - Dasypyrum villosum & 14 & ca.6.0 & ca.26AT & ca.26AT & ca.14AT & $2 \mathrm{~T}-\mathrm{GC}$ & $\mathrm{T}+\mathrm{I}+\mathrm{P}$ & $\begin{array}{l}\text { Cremonini et al. (1994); Pignone } \\
\text { et al. (1995) }\end{array}$ \\
\hline POA - Festuca rubra & 42 & ca.5.5 & ca. 70 & - & - & - & $\mathrm{T}$ & Bailey and Stace (1992) \\
\hline POA - Hordeum vulgare & 14 & ca. 11.7 & ca. 20 & ca. 62 & - & $4 \mathrm{I}$ & $\mathrm{T}+\mathrm{I}$ & Kakeda et al. (1991) \\
\hline POA - Secale cereale & 14 & 9.1 & $28 \mathrm{AT}$ & ca.40AT-N & $14 \mathrm{~N}$ & 2I-GC & $\mathrm{T}+\mathrm{I}+\mathrm{P}$ & $\begin{array}{l}\text { Sarma and Natarajan (1973); } \\
\quad \text { Mukai et al. (1992) }\end{array}$ \\
\hline POA - Triticum longissimum & 14 & ca.9.0 & 28 & 92 & 14 & $4 \mathrm{I}$ & $\mathrm{T}+\mathrm{I}+\mathrm{P}$ & Friebe et al. (1993) \\
\hline RAN - Aconitum sanyoense & 16 & ca. 6.0 & $\begin{aligned} & 4 \mathrm{GC} \\
+ & 14 \mathrm{AT}\end{aligned}$ & $4 \mathrm{AT}$ & 6 AT- $2 \mathrm{~N}$ & $2 \mathrm{~T}-\mathrm{GC}$ & $\mathrm{T}$ & Okada (1991) \\
\hline RAN - Anemone blanda ${ }^{1}$ & 16 & ca. 12.0 & - & $40 \mathrm{AT}$ & - & $2 \mathrm{~T}$ & I & $\begin{array}{l}\text { Marks and Schweizer (1974); } \\
\text { Hagemann et al. (1993) }\end{array}$ \\
\hline RAN - Helleborus foetidus ${ }^{2}$ & 32 & ca.7.4 & - & - & - & $6 \mathrm{~T}-\mathrm{GC}$ & - & D’Amato and Bianchi (1989) \\
\hline RAN - Nigella damascena & 12 & ca.11.0 & - & - & 12 & $2 \mathrm{~T}$ & $\mathrm{P}$ & Marks (1975) \\
\hline SAL - Azima tetracantha & 22 & 9.2 & ca. $28 \mathrm{~N}$ & ca.6N & $22 \mathrm{~N}$ & $2 \mathrm{I}-\mathrm{GC}$ & $\mathrm{T}+\mathrm{P}$ & Guerra (1989) \\
\hline SOL - Cestrum fasciculatum & 16 & ca. 6.0 & - & $\begin{array}{l}\text { ca.7GC } \\
+16 \mathrm{AT}\end{array}$ & $14 \mathrm{~N}$ & 4T-GC & $\mathrm{I}+\mathrm{P}$ & Berg and Greilhuber (1993) \\
\hline SOL - Cyphomandra luteoalba & 24 & 6.1 & 10 & 46 & - & $2 \mathrm{~T}$ & I & Pringle and Murray (1993) \\
\hline TRI - Paris tetraphylla & 10 & 22.7 & 8 & 6 & 10 & $2 \mathrm{~T}$ & $\mathrm{~T}+\mathrm{P}$ & Miyamoto and Kurita (1990) \\
\hline
\end{tabular}

to average chromosome size, based on the fact that the heteropycnotic characteristics of the chromatin of species with small, medium and large chromosomes are frequently different, resulting in different structural types of interphase nuclei (Delay, 1949; Guerra, 1987). Small chromosomes $(<3.0 \mu \mathrm{m})$ usually have arreticulate or pro-chromosome nuclei, which present early condensed proximal areas in prophase, e.g., heterochromatic blocks. On the other hand, large chromosomes $(>5.0 \mu \mathrm{m})$ usually have reticulate or eureticulate nuclei, with more or less homogeneous chromosome condensation. Medium-sized chromosomes $(>3.0<5.0 \mu \mathrm{m})$ display semi-reticulate nuclei with irregular and variable chromosome condensation (Delay, 1949; Guerra, 1987). This correlation is most evident between DNA amount and nuclear interphase type (Barlow, 1977).
However, since no DNA amount estimates were available for many of the species included, nuclear interphase type was correlated with average chromosome size.

The chromosome size was preferentially based on measurements supplied by the referred authors, although in the many cases where the chromosome size was not referred to in the paper, but a scale bar was presented in the photos or idiograms, a length estimation was made with the help of the scale. In these species the calculated chromosome size are more inaccurate, since such photographs show the banding pattern, but not necessarily with a representative chromosome size. In Table I these values are indicated as circa (ca.).

Whenever possible, the chromosome size estimated from conventionally stained cells was adopted, since the 
procedure used for C-banding or fluorochrome staining can apparently change the chromosome size. Schwarzacher and Schweizer (1982), for instance, reported an increase in size of up to $50 \%$ for chromosomes of Cephalanthera cells after C-banding, in comparison with those stained with Feulgen, while Moscone et al. (1996) observed that Capsicum chromosomes stained with fluorochrome could be up to $1 / 3$ larger than conventionally stained ones. On the other hand, Cyphomandra chromosomes treated with C-banding techniques were reduced to a third of the size of those stained with orcein (Pringley and Murray, 1993). In some cases, as in Arabidopsis thaliana and Arachis hypogaea, chromosome measurements made by other authors with conventional staining were used, since it was considered that any errors resulting from intraspecific polymorphism would be smaller than those arising from the measurement of a single cell. In any case, the chromosome size presented is just an approximation of the real size, used to separate the species into the three groups.

In this paper the position of the bands was classified as proximal when located in the proximal region or immediately after the primary constriction, as telomeric when located in the terminal regions of the chromosome, and as interstitial or intercalar when they occupied neither of the chromosome arm extremities. When the band occupied the whole chromosome arm, it was classified as telomeric or proximal depending on the dominant band pattern in the karyotype.

Concerning $\mathrm{HC}$ reactivity in relation to base-specific fluorochromes, the bands were classified as AT, GC or N (for neutral), depending on how they reacted with fluorochromes that preferentially stain DNA sequences rich in AT or GC. Species analyzed with the fluorochromes DAPI, quinacrine, Hoechst 33258 or CMA are indicated in Table I by the numbers $1,2,3$ or 4 , respectively, after the species name. The other species with an indication of main base composition but without a number were stained with CMA plus DAPI.

The bands associated with the NOR can involve the secondary constriction and/or the chromatin adjacent to this region, and for this kind of band the description in the papers was more important than photographs, since secondary constrictions have very variable expression and may not be expressed in that cell (Sato et al., 1980).

\section{RESULTS AND DISCUSSION}

In spite of the great variability known in $\mathrm{HC}$ distribution patterns, drastic and discontinuous changes within a related group of species are not common. In most of the genera in which data were available for at least five species, the number of bands and the $\mathrm{HC}$ amount varied but the general pattern was relatively well conserved, as in Anacyclus (Schweizer and Ehrendorfer, 1976), Secale (Bennett et al., 1977), Vigna (Zheng et al., 1991; Galasso et al., 1996b) and Citrus (Guerra, 1993a; Miranda et al.,
1997). The diversity was much higher in genera with karyotypes exhibiting numerous interstitial bands, like Anemone (Marks and Schweizer, 1974), Scilla (Greilhuber, 1982), and Tulipa (Blakey and Vosa, 1982). Data from very different, non-angiosperm taxa, like some gymnosperm or bryophyte genera, also show similar tendencies (see Tanaka and Hizume, 1980; MacPherson and Filion, 1981; Newton, 1986a,b; Davies et al., 1997).

Considering Table I as a representative sample of angiosperms, the genera and species most frequently analyzed with C-banding techniques are those with large chromosomes, like Triticum, Gibasis, Allium, Scilla, etc. Most of these genera are monocotyledons, whereas those with small chromosomes and only a few studied species are mainly dicotyledons. The diploid number of the sampled species is quite representative of angiosperms, although very high numbers are not represented. No relationship between chromosome number and any $\mathrm{HC}$ characteristic was found.

\section{Frequency of telomeric, interstitial, and proximal C-bands}

Table II presents the frequency of species with telomeric, interstitial or proximal C-bands, in relation to chromosome size. In general, C-bands were slightly more frequent in the proximal region than in other regions. Considering only the karyotypes with $\mathrm{HC}$ restricted to a single chromosome region one can observe that it was found in 33 of the 105 species, 23 of which had proximal bands, although these numbers may contain some bias. The frequency of telomeric bands may be overestimated due to the common occurrence of NOR-HC in this region, which is not always identified with this technique and may be wrongly counted as common C-bands. On the other hand, the very reduced frequency of interstitial $\mathrm{HC}$ blocks in small chromosomes may be partly due to technical difficulties in localizing these bands on the arms of very small chromosomes.

The distribution of C-bands seems to depend at least partly on chromosome size. Proximal bands, in general, were more common in karyotypes with small chromosomes, decreasing in frequency with increasing chromo-

Table II - Number and percentage of species analyzed in Table I with telomeric, interstitial or proximal bands.

\begin{tabular}{|lclll|}
\hline \multirow{2}{*}{$\begin{array}{l}\text { Average } \\
\text { chromosome } \\
\text { size }\end{array}$} & $\begin{array}{c}\text { Number of } \\
\text { species in each } \\
\text { size category }(\%)\end{array}$ & Telomeric & Interstitial & Proximal \\
\cline { 3 - 5 } & $34(32.4)$ & $20(58.8)^{*}$ & $7(20.6)$ & $28(82.4)$ \\
Small & $27(25.7)$ & $16(59.3)$ & $16(59.3)$ & $19(70.4)$ \\
Medium & $44(41.9)$ & $30(68.2)$ & $30(68.2)$ & $25(56.8)$ \\
Large & 105 & 66 & 53 & 72 \\
Total & & 63 & & \\
\hline
\end{tabular}

*The sum of percentages in each size category is over 100 because some species have bands in two or three positions. 
some size (Table II). Furthermore, karyotypes with only proximal bands were found in 11 of the 34 species with small chromosomes but in only 12 of the 71 species with large and medium-sized chromosomes, suggesting that this region develops or conserves $\mathrm{C}$-bands more frequently.

The predominance of proximal bands in karyotypes with small chromosomes is more evident in the distribution of generalized equilocal bands, considered here as those bands occurring in the same region in at least $80 \%$ of the chromosomes of a karyotype. In general, such bands were less common in species with small chromosomes (Table III). However, among 24 species with small chromosomes and generalized equilocal bands, 21 showed generalization in the proximal region, three in the telomeric region and only one in the interstitial region. Such contrast is far less evident in species with medium or large chromosomes (Table III). Very often generalized proximal bands are largely conserved throughout a genus, as in Crepis (Ikeda, 1988) or Sesbania (Forni-Martins and Guerra, 1999). The frequencies of generalized bands in Table III are overestimated due to the a priori selection of species with the maximum number of bands in those genera with a single representative, although this bias was the same for every chromosome size class.

Generalized proximal HC has also been observed in several species only when using modified C-banding methods, as in onion (Fiskesjo, 1974; Cortés and Escalza, 1986), or after in situ hybridization, as in Vigna unguiculata (Guerra et al., 1996), or after sequential CMA/DAPI staining and C-banding, as in Cardiospermum grandiflorum (Hemmer and Morawetz, 1990). In some other species proximal C-bands have been observed only occasionally. Figure 1 illustrates the occurrence of occasional $\mathrm{C}$-bands in Santolina (Asteraceae-Anthemidae). In two diploid spe-

Table III - Number and percentage of species with generalized equilocal bands in different chromosomal positions for chromosomes of different sizes (based on Table I).

\begin{tabular}{|lcccccc|}
\hline \multirow{2}{*}{$\begin{array}{l}\text { Average } \\
\text { chromosome size }\end{array}$} & \multicolumn{2}{c}{ Number of species } & & \multicolumn{3}{c|}{ Band position } \\
\cline { 2 - 3 } \cline { 5 - 7 } & Total & With generalized bands & & Telomeric & Interstitial & Proximal \\
\hline Small & 34 & $24(70.6)^{*}$ & & $03(12.5)^{*}$ & $01(4.2)$ & $21(87.5)$ \\
Medium & 27 & $26(96.3)$ & & $11(42.3)$ & $04(15.4)$ & $16(61.5)$ \\
Large & 44 & $36(81.8)$ & & $23(63.8)$ & $16(44.4)$ & $23(63.8)$ \\
Total & 105 & $86(81.9)$ & & $37(43.0)$ & $21(24.4)$ & $59(65.1)$ \\
\hline
\end{tabular}

*The sum of percentages for each size category is over 100 because some species have generalized bands in two or three positions.
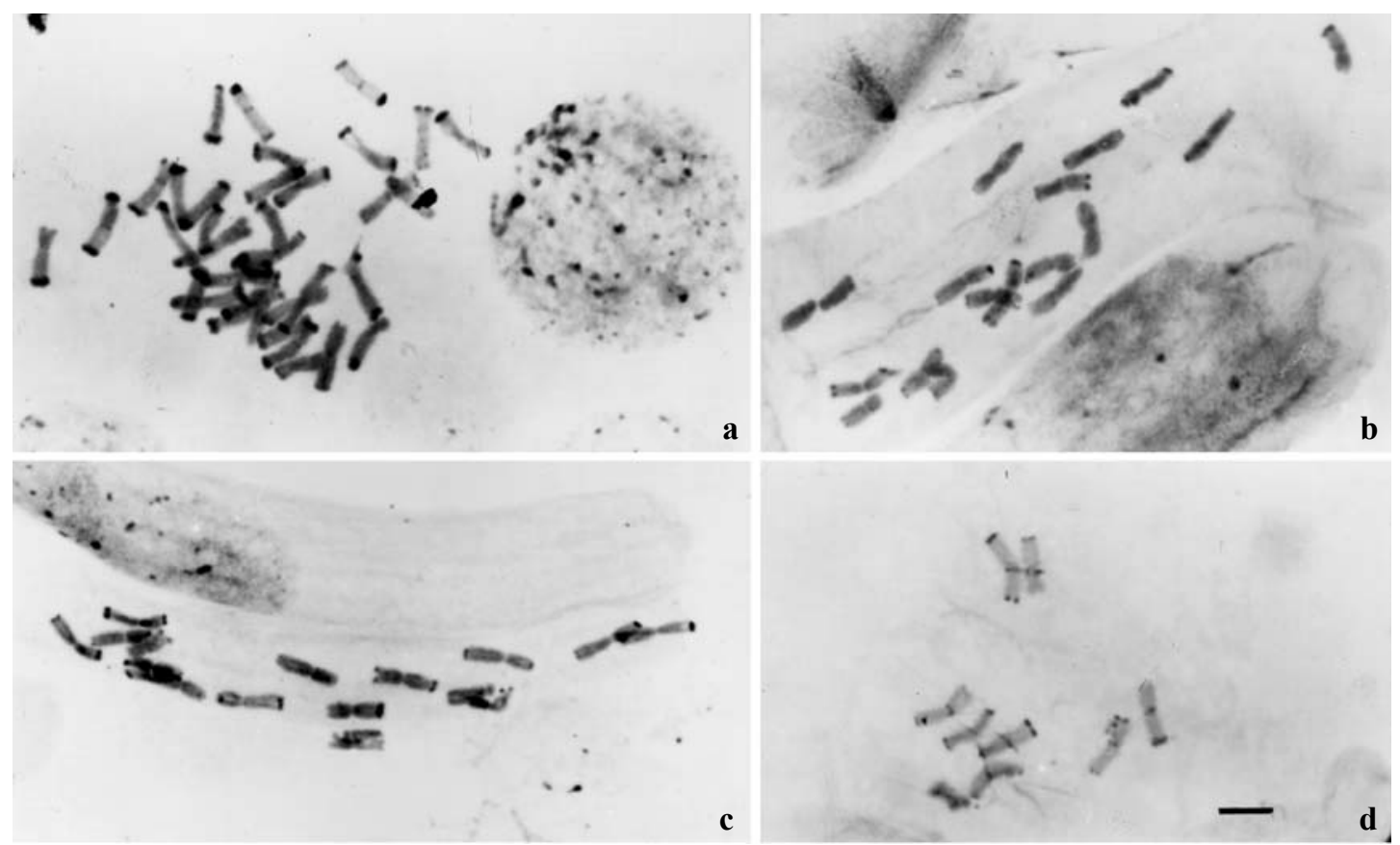

Figure 1 - C-banded metaphase chromosomes of Santolina species. a, Santolina $\mathrm{sp} .(2 \mathrm{n}=36) . \mathbf{b}$, S. rosimarinifolia $(2 \mathrm{n}=18)$. c, d, S. chamaecyparissus $(2 \mathrm{n}=18)$. Note proximal bands in most chromosomes of the tetraploid species and at the partial metaphase in $\mathbf{d}$. Bar in $\mathbf{d}$ represents $5 \mu \mathrm{m}$. 
cies, $S$. rosimarinifolia and $S$. chaemacyparissus, only telomeric bands were found, whereas in a tetraploid, Santolina sp., telomeric and proximal bands were always observed (Figure 1a-c). However, in a single slide of S. rosimarinifolia, proximal bands were found in all chromosomes (Figure 1d). Such occasional results are certainly not rare, but usually go unreported. These data suggest that the occurrence of any detectable kind of proximal $\mathrm{HC}$ is much higher than that observed here, and it may be a common feature of all angiosperm chromosomes (see also Vosa, 1985).

Another interesting aspect is that the occurrence of generalized bands in the interstitial region was not only much lower but almost always accompanied by generalization in another region, since 15 of 20 species with generalized insterstitial bands also presented generalization in the telomeric or proximal region.

\section{NOR associated heterochromatin}

Secondary constrictions were not observed or not mentioned in only 14 of the 105 species of Table I. They are usually more difficult to visualize when they are very small or terminally located in the chromosomes (Guerra et al., 1997; Pedrosa et al., 2000). In general, the secondary constrictions were located in the short arm, close to the telomere, as observed by Lima de Faria (1976a), and the NOR-HC was located distally, occupying one or both sides of the constriction.

The NOR-HC is clearly differentiated from other $\mathrm{HC}$ types because it contains rDNA genes, although it may also contain repeated sequences not related to the NOR, such as the 120-bp repeat unit of rye (Cuadrado and Jouve, 1994). Analysis of rDNA site distribution by in situ hybridization shows that they are always present in the NOR and often in other regions where secondary constrictions have not been located. In Vigna unguiculata, for instance, only one or two chromosomes with secondary constrictions were observed, whereas $10 \mathrm{rDNA}$ sites were revealed by FISH (Guerra et al., 1996), eight of them terminally located. NOR-HC often stains differently from other HC types (Sato et al., 1979; Guerra, 1988a) and in extreme cases it does not react positively after $\mathrm{C}$-banding or fluorochrome staining, as in Tulbaghia pulchella (Vosa, 1970), Buglossoides purpurocaerulea (D'Amato et al., 1981), Cyprepedium segawai (Kondo et al., 1994; Hoshi et al., 1995), Lathyrus aphaca, L. tingitanus (Ünal et al., 1995) and Orchis coriophora (D'Emerico et al., 1996).

\section{Bands observed with fluorochromes}

The most commonly used fluorochromes were CMA and DAPI, and among the 58 species analyzed with fluorochromes in Table I, 44 were stained with this fluorochrome combination, almost always using the double-staining tech- nique proposed by Schweizer (1976). In some cases, besides CMA and DAPI, other fluorochromes were also used as primary stains (Hoshi et al., 1995; Sato and Yoshioka, 1984) or as counterstains (Deumling and Greilhuber, 1982; Jamilena et al., 1990; Cuellar et al., 1996). Quinacrine was the third most frequently used fluorochrome (10 species), followed by Hoechst 33258 .

Bands observed with fluorochromes were also positively stained after C-banding, although not all C-bands were differentiated by fluorochromes. In some species, however, a small number of fluorescent bands were found at sites where C-bands were not detected, as in Aconitum sanyoense (Okada, 1991) and Cestrum fasciculatum (Berg and Greilhuber, 1993). This fact, together with the apparent lack of NOR associated C-bands in some species, indicates once again that not all heterochromatin is detectable with the most usual C-banding techniques (see, Vosa, 1985).

The relationship between the intensity of the brightness of a fluorochrome stained chromatin and its base composition was originally established for cells not treated with C-banding or any other treatment promoting DNA denaturation-renaturation or preferential extraction of the euchromatin (Casperson et al., 1969; Schweizer, 1976; Sumner, 1990). However, some authors have used fluorochrome staining after the C-banding technique, obtaining bright bands which may not be an indication of AT- or GC-richness (Silva and Guerra, 1998). Bennett et al. (1995), for instance, after chromosome staining with quinacrine or DAPI of Zingeria biebersteiniana $(\mathrm{n}=2)$, observed fluorescent bands only in the proximal region of one chromosome pair. Using C-banding plus the same fluorochromes, they observed proximal DAPI+ bands in both chromosome pairs and a terminal band in one of them, coinciding with Giemsa stained C-bands. These same DAPI+ bands were also observed after in situ hibridization. Vosa (1976a,b) observed that the NOR-HC of some species was positive for Hoechst and quinacrine after C-banding but negative for the same fluorochrome without pretreatment. Such fluorescent bands obtained only after C-banding were considered as neutral in Table I.

The most characteristic HC detected with fluorochromes was the NOR-HC, almost always CMA+ and DAPI-. The reaction intensity of CMA with this $\mathrm{HC}$ was variable. Most frequently it was more intense than with other GC-rich bands, but in Muscari comosum and Psygmorchis pusilla it was faintly stained or neutral. Interestingly, in Arabidopsis thaliana the NOR associated HC was apparently positive after staining with DAPI (Maluszynska and Heslop-Harrison, 1991; Ross et al., 1996), although its reaction with CMA is unknown. In this case, staining with CMA or mithramycin is important to verify whether or not a small CMA+ region exists in the secondary constriction itself or very close to it. Positive bands for DAPI or Hoechst, very close to the NOR, have been reported in several other species (Kenton, 1991; Cremonini et al., 1994). 


\section{Distribution of fluorochrome bands}

Most species have at least one pair of CMA+ bands, since all of them have at least one pair of NORs (Moravetz, 1986a; Röser, 1994; Guerra et al., in press). In some species there are one or two pairs of CMA+ blocks at a very similar chromosome position to that of the NOR, although no secondary constriction is observed associated with them. This occurs in Hedera helix (König et al., 1987), Cicer arietinum (Galasso et al., 1996a) and Hypochoeris chillensis (Cerbah et al., 1995). However, after in situ hybridization with rDNA probes, these CMA bands are also often labelled, suggesting that it is the same type of $\mathrm{HC}$ (Galasso et al., 1996a; Cerbah et al., 1998).

In Table I, excluding the NOR bands, AT-rich blocks were found in 29 species, GC-rich in 19 species and neutral blocks in 23 species. Note that the total number of ATor GC-rich sites per karyotype is not under consideration, but rather the number of species exhibiting at least one such site per chromosomal region. AT-rich sites were more frequently found at the interstitial region in species with medium and large chromosomes size (Table IV). Particularly in the case of bimodal karyotypes with long acrocentrics and small metacentrics or acrocentrics, interstitial bands were almost always AT-rich, as in some Brimeura species (Vosa, 1979), Fortunatia arida, Muscari comosum, Ornithogalum tenuifolium, Eleutherine bulbosa and Cephalanthera longifolia (Table I). A noteworthy exception was Nothoscordum fragrans, with interstitial bands that were positive for mithramycin and chromomycin A3 and negative for quinacrine (Sato and Yoshioka, 1984). Other karyotypes basically composed of long acrocentrics, like Anemone blanda and Vicia faba (Table I), were also characterized by interstitial AT-rich bands.

Among GC-rich bands, some were certainly non-identified rDNA sites, suggesting that the proportion of spe-

Table IV - Distribution of C-bands with different base composition in karyotypes of small, medium and large chromosomes (based on Table I).

\begin{tabular}{|c|c|c|c|c|c|}
\hline \multirow{2}{*}{$\begin{array}{l}\text { Band } \\
\text { position }\end{array}$} & \multirow{2}{*}{$\begin{array}{l}\text { Main base } \\
\text { composition }\end{array}$} & \multicolumn{3}{|c|}{ Average chromosome size } & \multirow[t]{2}{*}{ Total } \\
\hline & & small & medium & large & \\
\hline \multirow[t]{3}{*}{ Telomeric } & $\mathrm{GC}$ & 04 & 04 & 06 & 14 \\
\hline & AT & 03 & 04 & 08 & 15 \\
\hline & $\mathrm{N}$ & - & 03 & 01 & 04 \\
\hline \multirow{3}{*}{ Intercalar } & $\mathrm{GC}$ & 02 & 05 & 05 & 12 \\
\hline & $\mathrm{AT}$ & 01 & 07 & 11 & 19 \\
\hline & $\mathrm{N}$ & 02 & 02 & 03 & 07 \\
\hline \multirow[t]{3}{*}{ Proximal } & $\mathrm{GC}$ & - & 03 & 01 & 04 \\
\hline & AT & 03 & 07 & 05 & 15 \\
\hline & $\mathrm{N}$ & 08 & 08 & 06 & 22 \\
\hline \multirow[t]{3}{*}{ Total } & $\mathrm{GC}$ & 06 & 12 & 12 & 30 \\
\hline & AT & 07 & 18 & 24 & 49 \\
\hline & $\mathrm{N}$ & 10 & 13 & 10 & 33 \\
\hline
\end{tabular}

cies with AT-rich $\mathrm{HC}$ is even higher. Nevertheless, in some taxa, GC-rich bands are very diversified and highly dominant or even exclusive, as in the genus Capsicum (Moscone et al., 1996), in the subfamily Aurantioideae (Guerra et al., in press) or in the family Lemnaceae (Geber, 1989).

Equilocal bands almost always stain in the same way with fluorochromes, suggesting that most of these bands are made up of the same or very similar repeats. Analyses in several organisms with in situ hybridization of specific satellite DNA fractions have shown that such repeats usually have equilocal distribution (Appels et al., 1978; Badaeva et al., 1996; Brandes et al., 1995). In Aegilops, for instance, a specific satellite sequence was observed in the terminal and subterminal regions of all species investigated, as well as in other chromosomal regions (Badaeva et al., 1996). In some species, two or more unrelated satellite DNAs have been observed occupying the same equilocal sites (Brandes et al., 1995), which may explain those sites that stain positively with different base specific fluorochromes.

\section{CONCLUDING REMARKS}

The analysis of C-band patterns in a sample of over one hundred angiosperm karyotypes with different chromosome sizes showed that $\mathrm{HC}$ is not randomly distributed but rather that it is preferentially located. The NOR-HC is a notorious example, with a very marked distribution at subtelomeric sites. This $\mathrm{HC}$ type is very frequently, but not always, positively stained by $\mathrm{C}$-banding techniques and by fluorochromes with high affinity for GC-rich chromatin. The remaining $\mathrm{HC}$ is mainly AT-rich and, regardless of its DNA base composition, it has a generalized equilocal distribution. In small chromosomes the bands are conspicuously preferentially located in proximal regions. Such generalized proximal bands may be related to the high frequency of prochromosomal nuclei in species with small chromosomes and low DNA content (Delay, 1949; Barlow, 1977; Guerra, 1987).

The bands seen here showed a tendency to be preferentially distributed in some specific chromosome regions, regardless of distance from the centromere. Thus, generalized telomeric C-bands were found in similar- and dissimilar-sized arms of a single karyotype, as in Paris tetraphyla (Miyamoto and Kurita, 1990), Aconitum sanyoense (Okada, 1991) and Fortunatia arida (Fernández and Daviña, 1991). Likewise, NOR-HC was terminally located in karyotypes with similar-sized arms, as in Allium subvillosum (Jamilena et al., 1990), or different-sized arms, as in Paeonia tenuifolia (Schwarzacher-Robinson, 1986). Generalized interstitial C-bands can be also equidistant, as in Anemone blanda (Marks and Schweizer, 1974) and Lathyrus tingitanus (Ünal et al., 1995), or, more frequently, occupy different positions in interstitial regions, as in several species of Lilium (Smyth et al., 1989) and Cyphomandra (Pringle and Murray, 1993). 
One of the important assumptions in the heterochromatin dispersion model proposed by Schweizer and Loidl (1987) is that interstitial bands in long arms are equidistant to the terminal bands of short arms. Such symmetrical distribution was attributed to $\mathrm{HC}$ amplification and transposition occurring during mitotic interphase between nonhomologous chromosomes showing Rabl orientation. In the present sample, such interstitial bands corresponding to non-homologous terminal $\mathrm{HC}$ were sometimes observed, although often along with several non-equidistant interstitial bands, as in Gibasis karwinskyana (Kenton, 1978, 1991) and Secale cereale (Mukai et al., 1992). Chromosomes of Allium subvillosum, for instance, exhibited telomeric bands in all short arms and interstitial bands in all long arms, but, according to the idiogram of Jamilena et al. (1990), the interstitial bands were located at distances almost always larger than the longest of the short arms. Actually, an exact equidistancing is not expected. Since different chromosome arms may have different condensation/decondensation patterns (Okada, 1975; Fukui and Mukai, 1988), the distance between one band and the centromere in non-homologous arms may be quite different in metaphase and in interphase.

These data suggest that generalized bands are not just an accident due to chromatin proximity of more or less equidistant non-homologous regions but most probably are due to the functional or structural similarity of these regions. The equilocal or equidistant chromatin "contamination" by the same type of repetitive DNA sequence may be facilitated, but not determined, by Rabl orientation. This assumption is supported by $\mathrm{HC}$ distribution in species with holocentric chromosomes, which are free from the influence of Rabl orientation. Karyotypes of Drosera (Sheik and Kondo, 1995, 1996) and Rhynchospora (Vanzela et $a l$. in press), genera with holocentric chromosomes and belonging to widely different angiosperm families, exhibit $\mathrm{HC}$ distribution patterns similar to those with monocentric chromosomes. In both genera, generalized equilocal Cbands were found, which also gave identical fluorochrome reactions. In several species of Rhynchospora, Vanzela et al. (1998) observed the occurrence of multiple rDNA sites always distributed in the terminal regions. Similarly, satellite DNA sequences with generalized equilocal distribution were observed in the holocentric chromosomes of the peach potato aphid (Spence et al., 1998; Mandrioli et al., 1999). Therefore, HC equidistribution may not depend fundamentally on Rabl orientation and band-centromere distance, but rather on some structural or functional similarity of each chromosomal region that makes them equally receptive to the installation and/or amplification of the same or similar DNA sequence (Fry and Salser, 1977; Flavell, 1982).

\section{REFERENCES}

Aguiar-Perecin, M.L.R de (1985). Bandeamento-C e tipos de heterocromatina em milho. In: Tópicos de Citogenética e Evolução Vegetal de
Plantas (Aguiar-Perecin, M.L.R., Martins, P.S. and Bandel, G., eds.). Sociedade Brasileira de Genética, Ribeirão Preto, pp. 51-67.

Aguiar-Perecin, M.L.R. and Vosa, C.G. (1985). C-banding in maize II. Identification of somatic chromosome. Heredity 54: 37-42.

Ambros, P. and Schweizer, D. (1976). The Giemsa C-banded karyotype of Arabidopsis thaliana (L). Heynh. Arabidopsis Inf. Serv. 13: 167-171.

Appels, R., Driscoll, C. and Peacock, W.J. (1978). Heterochromatin and highly repeated DNA sequences in rye (Secale cereale). Chromosoma 70:67-89.

Badaeva, E.D., Friebe, B. and Gill, B.S. (1996). Genome differentiation in Aegilops. 1. Distribution of highly repetitive DNA sequences on chromosomes of diploid species. Genome 29: 293-306.

Bailey, J.P. and Stace, C.A. (1992). Chromosome banding and pairing behaviour in Festuca and Vulpia (Poaceae, Pooideae). Plant Syst. Evol. 182:21-28.

Barlow, P. (1977). Determinants of nuclear chromatin structure in angiosperms. Ann. Sci. Nat. Bot. Biol. Veg. 18: 193-206.

Baumann, T.W. (1971). Heterochromatin und DNS-Replikation bei Scilla sibirica. Exp. Cell Res. 64: 323-330.

Benko-Iseppon, A.M. and Morawetz, W. (1993). Cold-induced chromosome regions and karyosystematics in Sambucus and Viburnum. Bot. Acta 106: 183-191.

Bennett, M.D. (1982). Nucleotypic basis of the spatial ordering of chromosomes in eukaryotes and the implications of the order for genome evolution and phenotypic variation. In: Genome Evolution (Dover, G.A. and Flavell, R.B., eds.). Academic Press, London, pp. 239-261.

Bennett, M.D., Gustafson, J.P. and Smith, J.B. (1977). Variation in nuclear DNA in the genus Secale. Chromosoma 61: 149-176.

Bennett, S.T. and Thomas, S.M. (1991). Karyological analysis and genome size in Milium (Gramineae) with special reference to polyploidy and chromosomal evolution. Genome 34: 868-878.

Bennett, S.T., Leitch, I.J. and Bennett, M.D. (1995). Chromosome identification and mapping in the grass Zingeria biebersteiniana $(2 n=4)$ using fluorochromes. Chromosome Res. 3: 101-108.

Berg, C. and Greilhuber, J. (1993). Cold-sensitive chromosome regions and heterochromatin in Cestrum (Solanaceae): C. strigillatum, C. fasciculatum, and C. elegans. Plant Syst. Evol. 185: 133-151.

Blakey, D.H. and Vosa, C.G. (1982). Heterochromatin and chromosome variation in cultivated species of Tulipa subg. Leiostemones (Liliaceae). Plant Syst. Evol. 139: 163-178.

Brandes, A. Röder, M.S. and Ganal, M.W. (1995). Barley telomeres are associated with different types of satellite DNA sequences. Chromosome Res. 3: 315-320.

Buitendijk, J.H., Peters, A., Quené, R.-J. and Ramanna, M.S. (1998). Genome size variation and C-band polymorphism in Alstroemeria aurea, A. ligtu and A. magnifica (Alstroemeriaceae). Plant Syst. Evol. 212: $87-106$.

Cai, Q., Lu, S. and Chinnappa, C.C. (1987). Analysis of karyotype and Giemsa C-banding patterns in eight species of Arachis. Genome 29: 187-194.

Calderini, O., Puppilli, F., Cluster, P.D., Mariani, A. and Arcioni, S. (1996). Cytological studies of the nucleolus organizing regions in the Medicago complex: sativa - coerulea - falcata. Genome 39: 914-920.

Carvalho, R. and Guerra, M. (1999). Citogenética de nove espécies do gênero Manihot (Euphorbiaceae). I Simp. Latin-Am. Citogenét. Evol. Veget. (Resumos): 13.

Carvalho, C.R. and Saraiva, L.S. (1993). A new heterochromatin banding pattern revealed by modified HKG banding technique in maize chromosome. Heredity 70: 515-419.

Caspersson, T., Zech, L., Modest, E.J., Foley, G.E., Wagh, U. and Simonsson, E. (1969). DNA-binding fluorochromes for the study of the organization of the metaphase nucleus. Exp. Cell Res. 58: 141-152.

Cerbah, M., Coulaud, J., Godelle, B. and Siljak-Yakovlev, S. (1995). Genome size, fluorochrome banding, and karyotype evolution in some Hypochoeris species. Genome 38: 689-695.

Cerbah, M., Coulaud, J. and Siljak-Yakovlev, S. (1998). rDNA organization and evolutionary relationships in the Hypochaeris (Asteraceae). J. Hered. 89: 312-318.

Chow, C. and Larter, E.N. (1981). Centromeric banding in maize. Can. J. Genet. Cytol. 23: 255-258.

Cortés, F. and Escalza, P. (1986). Analysis of different banding patterns 
and late replicating regions in chromosomes of Allium cepa, A. sativum and A. nigrum. Genetica 71:39-46.

Cremonini, R., Colonna, N., Stefani, A., Galasso, I. and Pignone, D. (1994). Nuclear DNA content, chromatin organization and chromosome banding in brown and yellow seeds of Dasypyrum villosum (L.) Candargy. Heredity 72: 365-373.

Crosa, O. (1996). Sistemática e evolução das espécies da seção Inodorum Guag. do gênero Nothoscordum Kunth (Allieae, Alliaceae). Doctoral thesis, Universidade Federal do Rio Grande do Sul, Porto Alegre.

Cuadrado, A. and Jouve, N. (1994). Mapping and organization of highly repeated DNA sequences by means of simultaneous and sequential FISH and C-banding in 6x-triticale. Chromosome Res. 2: 331-337.

Cuellar, T., Belhassen, E., Fernández-Calvín, B., Orellana, J. and Bella, J.L. (1996). Chromosomal differentiation in Helianthus annuus var macrocarpus: heterochromatin characterization and rDNA location. Heredity 76: 586-591.

D'Amato, G. and Bianchi, G. (1989). Heterochromatin and Ag-Nor staining in some species of Helleborus (Ranunculaceae). Caryologia 42: 1926.

D'Amato, G., Bianchi, G., Capineri, R. and Marchi, P. (1980). Heterogeneity of heterochromatic segments and karyotype definition in Vicia melanops Sibth \& SM. Caryologia 33: 347-351.

D'Amato, G., Capineri, R. and Marchi, P. (1981). Heterochromatin localization in Buglossoides purpurocaerulea (L) I.M. Johnston (Boraginaceae): a further case of correspondence between $\mathrm{Q}$ and Feulgen bands. Caryologia 34: 395-400.

Davies, B.J., O'Brien, I.E.W. and Murray, B.G. (1997). Karyotypes, chromosome bands and genome size variation in New Zealand endemic gymnosperms. Plant Syst. Evol. 208: 169-185.

Delay, C. (1949). Recherches sur la structure des noyaux quiescents chez les phanérogames. Ver. Cytol. Cytophysiol. Veg. 10: 103-228.

D'Emerico, S., Pignone, D. and Bianco, P. (1995). Karyomorphological analysis and heterochromatin characteristics disclose phyletic relationship among $2 \mathrm{n}=32$ and $2 \mathrm{n}=36$ species of Orchis (Orchidaceae). Plant Syst. Evol. 200: 111-124.

Deumling, B. and Greilhuber, J. (1982). Characterization of heterochromatin in different species of the Scilla siberica group (Liliaceae) by in situ hybridization of satellite DNAs and fluorochrome banding. Chromosoma 84: 535-555.

Dyer, F.A. (1963). Allocyclic segments of chromosomes and the structural heterozygosity that they reveal. Chromosoma 13: 545-576.

Ebert, I., Greilhuber, J. and Speta, F. (1996). Chromosome banding and genome size differentiation in Prospero (Hyacinthaceae): diploids. Plant Syst. Evol. 203: 143-177.

Felix, L.P. and Guerra, M. Chromosome analysis in Psygmorchis pusilla (L.) Dodson et Dressler: the smallest chromosome number known in Orchidaceae. Caryologia (in press).

Fernández, A. and Daviña, J.R. (1991). Heterochromatin and genome size in Fortunatia and Camassia (Hyacinthaceae). Kew Bull. 46: 307-316.

Fernández, A. and Krapovickas, A. (1994). Cromosomas y evolución en Arachis. Bonplandia 8: 187-220.

Fiskesjo, G. (1974). Two types of constitutive heterochromatin made visible in Allium by a rapid C-banding method. Hereditas 78: 153-156.

Flavell, R. (1982). Sequence amplification, deletion and rearrangement: major sources of variation during species divergence. In: Genome Evolution (Dover, G.A. and Flavell, R.B., eds.). Academic Press, London, pp. 301-323.

Forni-Martins, E.R. and Guerra, M. (1999) Longitudinal differentiation in chromosomes of some Sesbania Scop. species (Fabaceae). Caryologia 52:97-103.

Forni-Martins, E.R., Franchi-Tanibata, N. and Cardelli de Lucena, M.A. (1994). Karyotypes of species of Sesbania Scop. (Fabaceae). Cytologia 59: 479-482.

Friebe, B., Tuleen, N., Jiang, J. and Gill, B.S. (1993). Standard karyotype of Triticum longissimum and its cytogenetic relationship with $T$. aestivum. Genome 36: 731-742.

Fry, K. and Salser, W. (1977). Nucleotide sequence of HS- $\alpha$ satellite DNA from kangaroo rat Dipodomys ordii and characterization of similar sequences in other rodents. Cell 12: 1069-1084.

Fuchs, J., Strehl, S., Brandes, A., Schweizer, D. and Schubert, I. (1998). Molecular-cytogenetic characterization of the Vicia faba genome - heterochromatin differentiation, replication patterns and sequence localization. Chromosome Res. 6: 219-230.

Fukui, K. and Mukai, Y. (1988). Condensation pattern as a new image parameter for identification of small chromosomes in plants. Jpn. J. Genet. 63: 359-366.

Galasso, I., Frediani, M., Cremonini, R. and Pignone, D. (1996a). Chromatin characterization by banding techniques, in situ hybridization, and nuclear DNA content in Cicer L. (Leguminosae). Genome 39: 258-265.

Galasso, I., Saponetti, L.S. and Pignone, D. (1996b). Cytotaxonomic studies in Vigna. III. Chromosomal distribution and reacting properties of the heterochromatin in five wild species of the section Vigna. Caryologia 49: 311-319.

Geber, G. (1989). Zur Karyosystematik der Lemnaceae. Dissertation zur Erlangung des Doktorgrades. Universität Wien, Wien.

Geber, G. and Schweizer, D. (1988). Cytochemical heterochromatin differentiation in Sinapsis alba (Cruciferae) using a simple air-drying technique for producing chromosome spreads. Plant Syst. Evol. 158: 97 106

Gill, B.S., Friebe, B. and Endo, T.R. (1991). Standard karyotype and nomenclature system for description of chromosome bands and structural aberrations in wheat (Triticum aestivum). Genome 34: 830-839.

Gitaí, J. and Guerra, M. (1999). Análise citogenética de três representantes do gênero Anarcadium (Anacardiaceae). I Simp. Latin-Am. Citogenét. Evol. Veget. (Resumos): 25.

Greilhuber, J. (1975). Heterogeneity of heterochromatin in plants: comparison of Hy- and C-bands in Vicia faba. Plant Syst. Evol. 124: 139156.

Greilhuber, J. (1979). C-band distribution, DNA content and base composition in Adoxa moschatellina (Adoxaceae), a plant with cold-sensitive chromosome segments. Plant Syst. Evol. 131: 243-259.

Greilhuber, J. (1982). Trends in der Chromosomenevolution von Scilla (Liliaceae). Stapfia 10: 11-51.

Greilhuber, J. and Loidl, J. (1983). On regularities of C-banding patterns, and their possible cause. Kew Chromosome Conference II: 344.

Greilhuber, J. and Speta, L. (1976). C-banded karyotypes in the Scilla hohenackeri group, S. persica, and Puschkinia (Liliaceae). Plant Syst. Evol. 126: 149-188.

Greilhuber, J. and Speta, F. (1978). Quantitative analyses of C-banded karyotypes, and systematics in the cultivated species of the Scilla siberica group (Liliaceae). Plant Syst. Evol. 129: 63-109.

Guerra, M. (1982). Padrão de bandas C em Crepis vesicaria L. Bol. Soc. Broteriana 55: 167-174.

Guerra, M. (1985). Cytogenetics of Rutaceae III. Heterochromatin patterns. Caryologia 38: 335-346.

Guerra, M. (1987). Cytogenetics of Rutaceae IV. Structure and systematic significance of interphase nuclei. Cytologia 52: 213-222.

Guerra, M. (1988a). Characterization of different types of condensed chromatin in Costus (Zingiberaceae). Plant Syst. Evol. 158: 107-115.

Guerra, M. (1988b). Mitotic and meiotic analysis of a pericentric inversion associated with a tandem duplication in Eleutherine bulbosa. Chromosoma 97: 80-87.

Guerra, M. (1989). The chromosomes of Azima tetracantha (Salvadoraceae). Plant Syst. Evol. 168: 83-86.

Guerra, M. (1993a). Cytogenetics of Rutaceae. V. High chromosomal variability in Citrus species revealed by CMA/DAPI staining. Heredity 71:234-241.

Guerra, M. (1993b). High amount of heterochromatin in a tropical tree species: Genipa americana L. (Rubiaceae). Cytologia 58: 427-432.

Guerra, M. and Nogueira, M.T.M. (1990). The cytotaxonomy of Emilia spp. (Asteraceae: Senecioneae) occurring in Brazil. Plant Syst. Evol. 170: 229-236.

Guerra, M., Kenton, A. and Bennett, M.D. (1996). rDNA sites in mitotic and polytene chromosomes of Vigna unguiculata (L.) Walp. and Phaseolus coccineus L. revealed by in situ hybridization. Ann. Bot. 78: $157-161$

Guerra, M., Pedrosa, A., Barros e Silva, A.E., Cornélio, M.T.M., Santos, K. and Soares Filho, W. dos S. (1997). Chromosome number and secondary constriction variation in 51 accessions of a Citrus germplasm bank. Braz. J. Genet. 20: 489-496.

Guerra, M., Santos, K.G.B., Barros e Silva, A.E. and Ehrendorfer, F. Cytogenetics of Rutaceae VI: Heterochromatin banding patterns in Auran- 
tioideae - a case of parallel chromosomal evolution. Am. J. Bot. (in press).

Heitz, E. (1933). Die Herkunft der Chromocentren. Planta 18: 571-636.

Heitz, E. (1957). Die Chromosomenstruktur im Kern während der Kernteilung und der Entwicklung des Organismus. In: Conference on Chromosomes. W.E.J. Tjeenk Willink Verlagsgesellschaft, Zwolle, pp. $1-22$.

Hemmer, W. and Morawetz, W. (1990). Karyological differentiation in Sapindaceae with special reference to Serjania and Cardiospermum. Bot. Acta 103: 372-383.

Hennig, W. (1999). Heterochromatin. Chromosoma 108: 1-9.

Hirai, K., Irifune, K., Tanaka, R. and Morikawa, H. (1995). Molecular and cytological characterization of a highly repeated DNA sequence in Raphanus sativus. Genome 38: 1237-1243.

Hizume, M., Ishida, F. and Murata, M. (1992). Multiple locations of the rRNA genes in chromosomes of pines, Pinus densiflora and P. thunbergii.Jpn. J. Genet. 67: 389-396.

Hoshi, Y., Kondo, K., Tanaka, R. and Karasawa, K. (1995). A comparison of $\mathrm{C}$-banding pattern in nine species of Cypripedium (Orchidaceae). Kromosomo 77: 2636-2645.

Ikeda, H. (1988). Karyomorphological studies on the genus Crepis with special reference to C-banding pattern. J. Sci. Hiroshima Univ. (Ser. C) 22:65-117

Ito, Y., Omura, M. and Nesume, H. (1993). Improvement of chromosome observation methods for Citrus. In: Techniques on Gene Diagnosis and Breeding (Hayashi, T., Omura, M. and Scott, N.S., eds.). FTRS, Tsukuba, pp. 31-38.

Jamilena, M., Rejón, C.R. and Rejón, M.R. (1990). Variation in the heterochromatin and nucleolar organizing regions of Allium subvillosum L. (Liliaceae). Genome 33: 779-784.

John B. (1988). The biology of heterochromatin. In: Heterochromatin Molecular and Structural Aspects (Verma, R.S., ed.). Cambridge University Press, Cambridge, pp. 1-47.

Jones, K. and Kenton, A. (1984). Mechanisms of chromosome change in the evolution of the tribe Tradescantieae (Commelinaceae). In: Chromosomes in Evolution of Eukaryotic Groups (Sharma, A.K. and Sharma, A., eds). CRC Press, Boca Raton, pp. 143-168.

Kakeda, K., Fukui, K. and Yamagata, H. (1991). Heterochromatic differentiation in barley chromosome revealed by $\mathrm{C}$ - and N-banding techniques. Theor. Appl. Genet. 81: 144-150.

Kamizyô, A. and Tanaka, N. (1978). Studies on the generative nuclear division I. Comparative analysis of somatic chromosomes in Allium fistulosum by means of C- and Q-banding patterns. Cytologia 43: 679-688.

Kenton, A. (1978). Giemsa C-banding in Gibasis (Commelinaceae). Chromosoma 65: 309-324

Kenton, A. (1991). Heterochromatin accumulation, disposition and diversity in Gibasis karwinskyana (Commelinaceae). Chromosoma 100: 467-478.

Kondo, K., Hoshi, Y. and Tanaka, R. (1994). Somatic chromosome differentiation in Cypripedium segawai Masamune and C. japonicum Thunberg. Cytologia 59: 115-120.

König, C. and Ebert, I. (1997). Computer-aided quantitative analysis of banded karyotypes, exemplified in C-banded Hyacinthoides italica s. 1. (Hyacinthaceae). Caryologia 48: 47-63.

König, C., Ebert, I. and Greilhuber, J. (1987). A DNA cytophotometric and chromosome banding study in Hedera helix (Araliaceae), with reference to differential DNA replication associated with juvenile-adult phase change. Genome 29: 498-503.

Koopman, W.J.M., De Jong, J.H. and De Vries, I.M. (1993). Chromosome banding patterns in lettuce species (Lactuca sect. Lactuca, Compositae). Plant Syst. Evol. 185: 249-257.

Lima-de-Faria, A. (1976a). The chromosome field I. Prediction of the location of ribosomal cistrons. Hereditas 83: 1-22.

Lima-de-Faria, A. (1976b). The chromosome field II. The location of "knobs" in relation to telomeres. Hereditas 83: 23-34.

Lima-de-Faria, A. (1983). Molecular Evolution and Organization of the Chromosome. Elsevier, Amsterdam.

Loidl, J. (1983). Some features of heterochromatin in wild Allium species. Plant Syst. Evol. 143: 117-131.

Lozano, R., Jamilena, M., Rejón, C.R. and Rejón, M.R. (1990). Character- ization of the chromatin of some liliaceous species after digestion with restriction endonuclease and sequential Giemsa, fluorochrome and silver staining. Heredity 64: 185-195.

MacPherson, P. and Filion, W.G. (1981). Karyotype analysis and the distribution of constitutive heterochromatin in five species of Pinus. J. Hered. 72: 193-198.

Maluszynska, J. and Heslop-Harrison, J.S. (1991). Localization of tandemly repetead DNA sequences in Arabidopsis thaliana. Plant J. 2: $159-166$

Mandrioli, M., Bizzaro, D., Manicardi, G.C., Gionghi, D., Bassoli, L. and Bianchi, U. (1999). Cytogenetic and molecular characterization of a highly repeated DNA sequence in the peach potato aphid Myzus persicae. Chromosoma 108: 436-442.

Marks, G.E. (1975). The Giemsa-staining centromeres of Nigella damascena. J. Cell Sci. 18: 19-25.

Marks, G. E. and Schweizer, D. (1974). Giemsa banding: karyotype differences in some species of Anemone and in Hepatica nobilis. Chromosoma 44: 405-416.

Masoud, S.A., Gill, B.S. and Jonhson, L.B. (1991). C-banding of alfalfa chromosomes: standard karyotype and analysis of a somaclonal variant. J. Hered. 82: 335-338.

Melo, N.F., Guerra, M., Benko-Iseppon, A.M. and Menezes, N.L. (1997). Cytogenetics and cytotaxonomy of Velloziaceae. Plant Syst Evol. 204: 257-273.

Mendelak, M. and Schweizer, D. (1986). Giemsa C-banded karyotypes of some diploid Artemisia species. Plant Syst. Evol. 151: 195-210.

Meritt, J.F. (1974). The distribution of heterochromatin in the genus $\mathrm{Ni}$ cotiana (Solanaceae). Am. J. Bot. 61: 982-994.

Miranda, M., Ikeda, F., Endo, T., Moriguchi, T. and Omura, M. (1997). Comparative analysis on the distribution of heterochromatin in Citrus, Poncirus and Fortunella chromosomes. Chromosome Res. 5: 86-92.

Miyamoto, J. and Kurita, S. (1990). C-band polymorphism in the karyotype of Paris tetraphylla A. Gray (Liliaceae). Cytologia 55: 301-313.

Mizianty, M. (1984a). Banding patterns in plant chromosomes. II. Bibliography (1970-1980) - Anthophyta. Acta Soc. Bot. Pol. 53 (Suppl. 1): 485-487.

Mizianty, M. (1984b). Banding patterns in plant chromosomes. II. Bibliography (1970-1980) - Anthophyta. Acta Soc. Bot. Pol. 53: 111-136.

Mizianty, M. (1985). Banding patterns in plant chromosomes. II. Bibliography (1970-1980) - Anthophyta. Acta Soc. Bot. Poloniae 54 (Suppl. 2): 193-194.

Molina, M.D.C. (1981). Caracterizacíon de los cromosomas de Zea mays con bandas C con Giemsa. Mendeliana 5: 3-8

Morawetz, W. (1981a). C-banding in Liriodendron tulipifera (Magnoliaceae): some karyological and systematic implications. Plant Syst. Evol. 138: 209-216.

Morawetz, W. (1981b). Karyologie und ökologisch-morphologische Differenzierung von Peumus boldus (Monimiaceae, Laurales). Plant Syst. Evol. 150: 119-141.

Morawetz, W. (1982). Morphologisch-ökologische Differenzierung, Biologie, Systematik und Evolution der neotropischen Gattung Jacaranda (Bignoniaceae). Österr. Akad. Wiss. Denkschriften 123: 1-184.

Morawetz, W. (1984). How stable are genomes of tropical woody plants? Heterozygosity in C-banded karyotypes of Porcelia as compared with Annona (Annonaceae) and Drimys (Winteraceae). Plant Syst. Evol. 145: 29-39.

Morawetz, W. (1986a). Remarks on karyological differentiation patterns in tropical woody plants. Plant Syst. Evol. 152: 49-100.

Morawetz, W. (1986b). Systematics and karyoevolution in Magnoliidae: Tetrameranthus as compared with other Annonaceae genera of the same chromosome number. Plant Syst. Evol. 154: 147-173.

Morawetz, W. and Waha, M. (1985). A new pollen type, C-banded and fluorochrome counterstained chromosomes, and evolution in Guatteria and related genera (Annonaceae). Plant Syst. Evol. 150: 119-141.

Moscone, E.A., Lambrou, M., Hunziker, A.T. and Ehrendorfer, F. (1993). Giemsa C-banded karyotypes in Caspicum (Solanaceae). Plant Syst. Evol. 186: 213-229.

Moscone, E.A., Lambrou, M. and Ehrendorfer, F. (1996). Fluorescent chromosome banding in cultivated species of Capsicum (Solanaceae). Plant Syst. Evol. 202: 37-63.

Mukai, Y., Friebe, B. and Gill, B.S. (1992). Comparison of C-banding pat- 
terns and in situ hybridization sites using highly repetitive and total genomic rye DNA probes of "Imperial" rye chromosomes added to "Chinese Spring" wheat. Jpn. J. Genet. 67: 71-83.

Newton, M.E. (1986a). Bryophyte phylogeny in terms of chromosome cytology. J. Bryol. 14: 43-57.

Newton, M.E. (1986b). Pellia borealis Lorbeer: its cytological status and discovery in Britain. J. Bryol. 14:215-230.

Okada, H. (1975). Karyomorphological studies of wood Polycarpicae. $J$. Sci. Hiroshima Univ. (Ser. B, Div. 2) 15: 115-200.

Okada, H. (1991). Correspondence of Giemsa C-band with DAPI/CMA fluorochrome staining pattern in Aconitum sanyoense (Ranunculaceae). Cytologia 56: 135-141.

Pedrosa, A., Schweizer, D. and Guerra, M. (2000). Cytological heterozygosity and the hybrid origin of sweet orange (Citrus sinesis (L) Osbeck). Theor. Appl. Genet. 100: 361-367.

Pendás, A.M., Morán, P. and Garcia-Vázquez, E. (1993). Ribosomal RNA genes are interspersed throughout a heterochromatic chromosome arm in Atlantic salmon. Cytogenet. Cell Genet. 63: 128-130.

Pierozzi, N.I. and Mendaçolli, S.L.J. (1997). Karyotype and C-band analysis in two species of Genipa L. (Rubiaceae, Gardenieae Tribe). Cytologia 62: 81-90.

Pignone, D., Galasso, I., Rossino, R. and Mezzanotte, R. (1995). Characterization of Dasypyrum villosum (L) Candargy chromosomal chromatin by means of in situ restriction endonucleases, fluorochromes, silver staining and C-banding. Chromosome Res. 3: 109-114.

Pijnacker, L.P. and Ferwerda, M.A. (1984). Giemsa C-banding of potato chromosomes. Can. J. Genet. Cytol. 26: 415-419.

Pringle, G.J. and Murray, B.G. (1993). Karyotypes and C-banding patterns in species of Cyphomandra Mart. ex Sendtner (Solanaceae) Bot. J. Linn. Soc. 111: 331-342.

Ramachandran, C., Brandenburg, W.A. and den Nijs, A.P.M. (1985). Infraspecific variation in C-banded karyotype and chiasma frequency in Cucumis sativus (Cucurbitaceae). Plant Syst. Evol. 151:31-41.

Ramsay, G. (1984). C-banding in Vicia species. In: Systems for Cytogenetic Analysis in Vicia faba L. (Chapman, G.P. and Tarawali, S.A., eds.) Nijhoff/Junk Publishers, Dordrecht, pp. 28-39.

Rees, H. and Hazarika, M.H. (1969). Chromosome evolution in Lathyrus. Chromosomes Today 2: 158-165.

Röser, M. (1994). Pathways of karyological differentiation in palms (Arecaceae). Plant Syst. Evol. 189: 83-122

Ross, K.J., Fransz, P. and Jone, G.H. (1996). A light microscopic atlas of meiosis in Arabidopsis thaliana. Chromosome Res. 4: 507-516.

Ruas, C.F., Ruas, P.M., Matzenbacher, N.I., Ross, G., Bernini, C. and Vanzela, A.L.L. (1995). Cytogenetic studies of some Hypochoeris species (Compositae) from Brazil. Am. J. Bot. 82: 369-375.

Sarma, N.P. and Natarajan, A.T. (1973). Identification of heterochromatic regions in the chromosomes of rye. Hereditas 74: 233-238.

Sato, S. and Yoshioka, T. (1984). Heterogeneity of heterochromatin segments in Nothoscordum fragrans chromosomes. Caryologia 37: 197205.

Sato, S., Kuroki, Y. and Ohta, S. (1979). Two types of color-differentiated C-banding positive segments in chromosomes of Nothoscordum fragrans, Liliaceae. Cytologia 44: 715-725.

Sato, S., Ohta, S. and Kuroki, Y. (1980). Heteromorphic appearance of acrocentric nucleolus organizer regions in Nothoscordum fragrans. Cytologia 45: 87-96.

Schubert, I. and Rieger, R. (1991). Characterization of plant chromosomes by means of banding techniques, differential incorporation of base analogues and in situ hybridization. The Eukaryotic Chromosome Structural and Functional Aspects (Obe, G. and Sobti, A., eds.). Springer Verlag and Narose Publishing House, New Delhi, pp. 31-46.

Schwarzacher, T. and Schweizer, D. (1982). Karyotype analysis and heterochromatin differentiation with Giemsa C-banding and fluorescent counterstaining in Cephalanthera (Orchidaceae). Plant Syst. Evol. 141:91-113.

Schwarzacher, T., Ambros, P. and Schweizer, D. (1980). Application of
Giemsa banding to orchid karyotype analysis. Plant Syst. Evol. 134: 293-297.

Schwarzacher-Robinson, T. (1986). Meiosis, SC-formation, and karyotype structure in diploid Paeonia tenuifolia and tetraploid P. officinalis. Plant Syst. Evol. 154: 259-274.

Schweizer, D. (1976). Reverse fluorescent chromosome banding with chromomycin and DAPI. Chromosoma 58: 307-324.

Schweizer, D. (1981). Counterstain-enhanced chromosome banding. Hum. Genet. 57: 1-14

Schweizer, D. (1983). Distamycin-DAPI bands: properties and occurrence in species. Kew Chromosome Conference II: 43-51.

Schweizer, D. and Ehrendorfer, F.W. (1976). Giemsa banded karyotypes, systematics, and evolution in Anacyclus (Asteraceae-Anthemideae). Plant Syst. Evol. 126: 107-148.

Schweizer, D. and Loidl, J. (1987). A model for heterochromatin dispersion and the evolution of C-band patterns. Chromosomes Today 9: 61-74.

Sheik, A.S. and Kondo, K. (1995). Differential staining with orcein, Giemsa, CMA and DAPI for comparative chromosome study of 12 species of Australian Drosera (Droseraceae). Austr. J. Bot. 82: 1278-1286.

Sheik, A.S. and Kondo, K. (1996). Comparative C-banding and fluorescent-banding analysis of seven species of Drosera (Droseraceae). Cytologia 6: 383-394

Siljak-Yakovlev, S. and Cartier, D. (1979). Utilisation de la colaration différentielle au Giemsa dans l'analyse des caryotypes de quatre Crepis. Rev. Cytol. Biol. Végét. - Bot. 2: 13-20.

Silva, A.E.B. and Guerra, M. (1998). Influência do processo de bandeamento C sobre a coloração com os fluorocromos CMA e DAPI em Emilia sonchifolia e Zephyrantes sp. Genet. Mol. Biol. 21 (Suppl.): 161.

Smyth, D.R., Kongsuwan, K. and Wisudharomn, S. (1989). A survey of Cband patterns in chromosomes of Lilium (Liliaceae). Plant Syst. Evol. 163: 53-69.

Spence, J.M., Blackman, R.L., Testa, J.M. and Ready, P.D. (1998). A 169 bp tandem repeat DNA marker for subtelomeric heterochromatin and chromosomal re-arrangement in aphids of the Myzus persicae group. Chromosome Res. 6: 167-175.

Sumner, A.T. (1990). Chromosome Banding. Unwin Hyman, London.

Tanaka, R. and Hizume, M. (1980). C-banding treatment for the chromosomes of some gymnosperms. Bot. Mag. 93: 167-170.

Ünal, F., Wallace, A.J. and Callow, R.S. (1995). Diverse heterochromatin in Lathyrus. Caryologia 48: 47-63.

Vanzela, A.L.L., Cuadrado, A., Jouve, N., Luceño, M. and Guerra, M. (1998). Multiple locations of the rDNA sites in holocentric chromosomes of Rhynchospora (Cyperaceae). Chromosome Res. 6: 345-349.

Vanzela, A.L.L., Guerra, M. and Luceño, M. Heterochromatin differentiation in holocentric chromosomes of Rhynchospora (Cyperaceae). Genet. Mol. Biol. (in press).

Vosa, C.G. (1970). Heterochromatin recognition with fluorochromes. Chromosoma 30: 366-372.

Vosa, C.G. (1976b). Heterochromatin classification in Vicia faba and Scilla sibirica. Chromosomes Today 5: 185-192.

Vosa, C.G. (1979). Heterochromatic banding patterns in the chromosomes of Brimeura (Liliaceae). Plant Syst. Evol. 132: 141-148.

Vosa, C.G. (1985). Chromosome banding in plants. In: Chromosome and Cell Genetics (Sharma, A.K. and Sharma, A., eds.). Gordon and Breach Science Publishers, London, pp. 79-104.

Vosa, C.G. (1997). Heterochromatin and ecological adaptation in Southern African Ornithogalum (Liliaceae). Caryologia 50: 97-103.

Watson, E.M. (1988). C-banding patterns in the Australian Bulbine (Liliaceae): the annual group, B. semibarbata s. lato. Plant Syst. Evol. 159: 1-17.

Yamasaki, N. (1971). Karyotypanalyse an Hand des Färbungsmusters der Metaphasechromosomen von Cypripedium debile und Trillium kamtschaticum. Chromosoma 33: 372-381.

Zheng, J., Nakata, M., Uchiyama, H. and Tanaka, R. (1991). Giemsa Cbanding patterns in several species of Phaseolus L. and Vigna Savi, Fabaceae. Cytologia 56: 459-466. 
